\title{
Monetary disequilibria and the Euro/Dollar exchange rate
}

\author{
Dieter Nautz \\ (Goethe-University, Frankfurt) \\ Karsten Ruth \\ (Deutsche Bundesbank)
}

Discussion Paper

Series 1: Economic Studies

No $18 / 2005$

Discussion Papers represent the authors' personal opinions and do not necessarily reflect the views of the Deutsche Bundesbank or its staff. 
Editorial Board:

Heinz Herrmann
Thilo Liebig
Karl-Heinz Tödter

Deutsche Bundesbank, Wilhelm-Epstein-Strasse 14, 60431 Frankfurt am Main, Postfach 1006 02, 60006 Frankfurt am Main

Tel +49 69 9566-1

Telex within Germany 41227, telex from abroad 414431, fax +49695601071

Please address all orders in writing to: Deutsche Bundesbank,

Press and Public Relations Division, at the above address or via fax +4969 9566-3077

Reproduction permitted only if source is stated.

ISBN 3-86558-059-9 


\begin{abstract}
Although stable money demand functions are crucial for the monetary model of the exchange rate, empirical research on exchange rates and money demand is more or less disconnected. This paper tries to fill the gap for the Euro/Dollar exchange rate. We investigate whether monetary disequilibria provided by the empirical literature on U.S. and European money demand functions contain useful information about exchange rate movements. Our results suggest that the empirical performance of the monetary exchange rate model improves when insights from the money demand literature are explicitly taken into account.
\end{abstract}

Keywords: Euro/Dollar Exchange Rate, Monetary Model, Money Demand Functions JEL Classification: F31, E41 



\section{Non-Technical Summary}

The assumption of stable money demand functions is of crucial importance for the monetary model of the exchange rate. The way economic fundamentals enter the money demand functions home and abroad determines how the equilibrium value of the exchange rate is affected by money supplies, incomes, and interest rates.

This paper examines whether the monetary approach to the exchange rate benefits from a more careful treatment of the underlying money demand functions. In particular, we make explicit use of recent results of the money demand literature when estimating an exchange rate equation. Incorporating monetary disequilibria - retrieved as deviations from the money demand relationships home and abroad - in the exchange rate equation we explicitly refer to the money demand functions as an input and not as an implicit by-product of the exchange rate analysis. Furthermore, including the monetary disequilibria home and abroad separately in the exchange rate equation sheds more light on the various channels affecting the exchange rate. We illustrate our approach with regard to the Euro/Dollar exchange rate.

We find that the Euro/Dollar exchange rate reacts to monetary disequilibria in Europe and the U.S. significantly and in a plausible way. Moreover, the use of wellspecified money demand functions tends to improve the empirical performance of monetary exchange rate equations in-sample and out-of-sample. This indicates that the explanatory power of empirical exchange rate models might be improved substantially by taking insights from the money demand literature into account. 


\section{Nicht-technische Zusammenfassung}

Im Rahmen des monetären Modells des Wechselkurses kommt der Annahme stabiler Geldnachfragefunktionen eine zentrale Bedeutung zu. Über die Gestalt der inländischen und ausländischen Geldnachfragefunktion ist bestimmt, in welcher Weise Geldmengen, Einkommen und Zinsen den Gleichgewichtswert des Wechselkurses beeinflussen.

In diesem Papier wird untersucht, ob die Erklärungskraft des monetären Modells durch eine sorgfältigere Berücksichtigung der zugrunde liegenden Geldnachfragebeziehungen erhöht werden kann. Insbesondere werden bisherige Ergebnisse der empirischen Literatur zur Geldnachfrage explizit für die Wechselkursanalyse verwandt. Hierzu werden monetäre Ungleichgewichte - d.h. kurzfristige Abweichungen von der inländischen sowie der ausländischen Geldnachfragefunktion - separat in die Wechselkursgleichung einbezogen. Dabei stützt sich die Analyse auf geschätzte Geldnachfragebeziehungen aus der empirischen Literatur. Anders als in bisherigen Studien ergeben sich Erkenntnisse über Geldnachfragefunktionen somit nicht residual aus der Wechselkursanalyse, sondern dienen als zentrale Information für die Untersuchung von Wechselkursdynamik. Darüber hinaus erlaubt es die separate Modellierung monetärer Ungleichgewichte, die verschiedenen Wirkungskanäle aufzuzeigen, über die der Wechselkurs beeinflusst wird. Der vorgeschlagene Ansatz wird am Beispiel des Euro/Dollar-Wechselkurses veranschaulicht.

Die empirischen Ergebnisse zeigen, dass der Euro/Dollar-Wechselkurs in plausibler und statistisch signifkanter Weise auf monetäre Ungleichgewichte in den USA und Europa reagiert. Weiterhin wird im Rahmen einer in-sample sowie out-of-sample Evaluation gezeigt, dass die Erklärungskraft von Schätzgleichungen für den Wechselkurs durch die Berücksichtigung wohlspezifizierter Geldnachfragefunktionen verbessert werden kann. Somit scheint sich die empirische Evidenz für das monetäre Modell des Wechselkurses zu erhöhen, wenn Erkenntnisse der Geldnachfrage-Literatur explizit in die Wechselkursanalyse einbezogen werden. 


\section{Contents}

1 Introduction 1

2 The Monetary Model of Exchange Rate Determination 3

2.1 A Brief Review of the Literature 3

2.2 Monetary Disequilibria and the Exchange Rate 5

3 Money Demand and Monetary Disequilibria $\quad 6$

3.1 Money Demand in the U.S. 6

$\begin{array}{lll}3.2 & \text { Money Demand in Europe } & 8\end{array}$

4 Monetary Disequilibria and the

Euro/Dollar Exchange Rate: Empirical Results 11

$\begin{array}{lll}\text { 4.1 Data } & 11\end{array}$

4.2 Structural Exchange Rate Equations 12

4.3 Out-of-Sample Evaluation: Predictive Regressions 14

4.4 In-Sample Evaluation: Dynamic Simulations 15

5 Concluding Remarks $\quad 16$

$\begin{array}{lr}\text { References } & 17\end{array}$ 


\section{List of Tables}

1 Recent Studies on Money Demand in Europe and the U.S. 9

2 Adjustment Coefficients of Structural and

Reduced Form Exchange Rate Equations

3 Out-of-Sample Forecast Comparison of Structural and Reduced Form Exchange Rate Equations

4 Root Mean Squared Errors of Dynamic Simulations

\section{List of Figures}

$1 \quad$ U.S. Monetary Disequilibria 1976:1-1998:4 


\section{Monetary Disequilibria and the Euro/Dollar Exchange Rate ${ }^{1}$}

\section{Introduction}

The assumption of stable money demand functions is of crucial importance for the monetary model of the exchange rate. The way economic fundamentals enter the money demand functions home and abroad determines how the equilibrium value of the exchange rate is affected by money supplies, incomes, and interest rates. As Smith and Wickens (1986) already emphasized, inappropriate modeling of money demand functions might be a major cause for the empirical failure of monetary exchange rate models. This paper examines whether the monetary approach to the exchange rate benefits from a more careful treatment of the underlying money demand functions.

A lot of recent contributions have confirmed the stability of money demand for the Euro Area, see Bruggeman et al. (2003) and the papers cited therein. For the U.S., convincing evidence for the stability of money demand is provided by Carlson et al. (2000). Given the stability of money demand functions, important requirements for applying the monetary approach to the Euro/Dollar exchange rate are actually met.

A distinguishing feature of this study is that we make explicit use of the results from recent money demand literature when estimating a monetary exchange rate equation. In particular, we investigate how the Euro/Dollar exchange rate responds to the monetary disequilibria identified by Carlson et al. (2000) and the literature on the European money demand. Using stable money demand functions as an input - and not as an implicit by-product - misspecified money demand functions should not longer be an issue for the exchange rate analysis. Furthermore, including the monetary disequilibria home and abroad separately in the exchange rate equation sheds more light on the various channels affecting the exchange rate.

\footnotetext{
1 Corresponding Authors:

Dieter Nautz, Goethe-University Frankfurt, Department of Money and Macroeconomics, Mertonstr. 17-21, 60054 Frankfurt (Main), Germany; e-mail: nautz@wiwi.uni-frankfurt.de

Karsten Ruth, Deutsche Bundesbank, Economics Department, Wilhelm-Epstein-Str. 14, 60431 Frankfurt (Main), Germany; e-mail: karsten.ruth@bundesbank.de
} 
Since the seminal paper by Meese and Rogoff (1983), a lot of work has been done aimed at improving the performance of empirical exchange rate models. In particular, MacDonald and Taylor (1994) established multivariate cointegration techniques in the exchange rate literature in order to model the dynamics of the exchange rate more appropriately. Yet the empirical evidence for the monetary exchange rate model is still mixed, see e.g. Cheung et al. (2002). Many contributions that claim to support the monetary model have severe problems identifying the cointegrating relation linking the exchange rate to economic fundamentals. Often, there is ambiguity with respect to the number of cointegrating relations. Moreover, as Rapach and Wohar (2004) recently emphasized, even when cointegration is supported by the data, the estimates for the cointegrating vector typically do not support the monetary model. In fact, the implied estimates of long-run income and interest rate elasticities of money demand obtained as by-products of the exchange rate analysis are often at variance with both economic theory and the results of the empirical money demand literature.

The closest references to this paper are La Cour and MacDonald (2000), and Moersch and Nautz (2001). These papers also argue that exchange rate dynamics could be better understood if the monetary building blocks of the model were to be treated more carefully. However, both papers do not integrate the results of the empirical money demand literature. This explains why La Cour and MacDonald (2000) fail to identify plausible money demand relations for the U.S. and Europe. For example, in sharp contradiction to the money demand literature conclusions, La Cour and MacDonald (2000) base their exchange rate analysis on money demand functions with zero income elasticities.

Our paper shows that the Euro/Dollar exchange rate reacts to monetary disequilibria in Europe and the U.S. significantly and in a plausible way. We find that the use of well-specified money demand functions tends to improve the empirical performance of monetary exchange rate equations in-sample and out-of-sample. The paper is structured as follows: Section 2 presents the standard reduced form approach to the monetary exchange rate model and discusses potential benefits of a more structural specification of the exchange rate equation. Section 3 briefly reviews recent studies on U.S. and European money demand. Following Carlson et al. (2000) we derive the corresponding monetary disequilibria as deviations from long-run money demand. In Section 4 we estimate standard reduced form as well as structural exchange rate equations where the exchange rate responds to deviations from PPP, the interest rate differential and the various monetary disequilibria proposed by the empirical money demand literature. The empirical performance of both kinds of exchange rate equations are compared in-sample and out-of-sample by means of dynamic simulations and predictive regressions. Section 5 summarizes our main results and concludes. 


\section{The Monetary Model of Exchange Rate Determination}

\subsection{A Brief Review of the Literature}

The standard flexible price monetary model of exchange rate determination assumes that stable long-run money demand functions for the home and foreign economy are linked by Purchasing Power Parity (PPP):

$$
\begin{array}{r}
m-p=\alpha y+\delta i+e c^{m} \\
m^{*}-p^{*}=\alpha^{*} y^{*}+\delta^{*} i^{*}+e c^{m^{*}} \\
s=p-p^{*}+e c^{p p p}
\end{array}
$$

Following the usual notation $m, p, y$, and $i$ denote money supply, price level, real income (all in logs), and an interest rate measuring the opportunity costs of holding money. An asterisk indicates foreign variables. $s$ is the logged nominal exchange rate expressed as units of domestic currency per unit of foreign currency, i.e. a rise in $s$ corresponds to a depreciation of the home currency. The $e c$-terms capture the stationary deviations from the three economic long-run relationships underlying the monetary model.

The empirical relevance of the monetary exchange rate model is still under debate. After a time of vanishing confidence in the model - mainly induced by the disappointing results of Meese and Rogoff (1983) - renewed interest in the monetary model arose with the development of new econometric methods. In particular, the use of cointegration techniques for the analysis of the long-run dynamics implied by the equations (1) to (3) increased the support to the monetary model, see e.g. MacDonald and Taylor (1994).

The empirical literature typically refers to the reduced form equation of the exchange rate, which links the equilibrium value of the exchange rate to macroeconomic fundamentals as follows:

$$
s_{t}=\beta_{0}+\beta_{1} m_{t}+\beta_{2} m_{t}^{*}+\beta_{3} y_{t}+\beta_{4} y_{t}^{*}+\beta_{5} i_{t}+\beta_{6} i_{t}^{*}+u_{t}
$$

The reduced form equation can be derived by substituting (3) into (1)-(2). In this case, one obtains $\beta_{1}=-\beta_{2}=1, \beta_{3}=-\alpha, \beta_{4}=\alpha^{*}, \beta_{5}=-\delta, \beta_{6}=\delta^{*}$. Since $u=e c^{p p p}+e c^{m^{*}}-e c^{m}$ is stationary, the long-run relations (1) to (3) imply that (4) is a cointegrating relation of the reduced system $z=\left(s, m, m^{*}, y, y^{*}, i, i^{*}\right)$. Note that the fundamental equation (4) is only identified if the cointegration rank of $z$ equals one. In fact, the main problem of the empirical exchange rate literature is the determination of the cointegration rank of $z$.

On the one hand, there are studies where the evidence for the existence of any cointegrating relation is only poor (see Kim and Mo 1995, p.355; Mark 1995, pp.208). 
Recent work on the monetary model by Groen $(2000,2002)$ explains the absence of cointegration by the low power properties of cointegration tests in small samples. Consequently, he proposes the application of panel data techniques to solve the 'time span problem'. In fact, exploiting the cross-section dimension of a multi-country panel often supports the existence of a cointegrating relation; see e.g. Oh (1999), Mark and Sul (2001) Rapach and Wohar (2004). Alternatively, Rapach and Wohar (2002) expand the time dimension by using long spans (i.e. of about a century) of data. They show that deviations from the monetary model are highly persistent near-unit root processes, which might be responsible for the difficulties in finding support for cointegration when using short time spans of data. ${ }^{2}$

On the other hand, there might be more than one cointegrating vector (see MacDonald and Taylor 1994; Moosa 1994). In this case, the long-run equilibrium value of the exchange rate given by (4) is not uniquely determined. As a consequence, determining the cointegrating vector most consistent with the monetary model is often viewed as a matter of judgement. Note, however, that even this vector may exhibit implausible estimates for the income and interest elasticities or even wrong signs of the coefficients, see MacDonald and Taylor (1994). In line with uncovered interest rate parity, a natural candidate for a second cointegrating relation is a stationary interest rate differential $(i r d)$ :

$$
i-i^{*}=e c^{i r d} .
$$

A stationary interest rate differential implies that the long-run coefficients $\beta_{5}$ and $\beta_{6}$ in (4) are not identified. For any real number $\lambda$, there is an equivalent fundamental equation with $\beta_{5}=(\lambda-\delta)$ and $\beta_{6}=-\left(\lambda-\delta^{*}\right)$ associated with a different equilibrium value of the exchange rate. As a consequence, the deviation from the equilibrium exchange rate defined by the stationary error-correction term $u=e c^{p p p}+e c^{m^{*}}-e c^{m}-\lambda e c^{i r d}$ is also not identified. The importance of interest rate differentials for the specification of exchange rate relationships has been emphasized by e.g. MacDonald and Marsh (1997), and La Cour and MacDonald (2000).

A further caveat of the empirical exchange rate literature refers to parameter restrictions. In particular, the hypothesis of a unit coefficient for relative money (i.e. $\beta_{1}=-\beta_{2}=1$ ), which follows from the fundamental equation of the exchange rate, is typically not easily accepted by the data. Some recent contributions restrict the attention to relative money supplies and incomes. This implies equality restrictions

\footnotetext{
${ }^{2}$ Notice further that cointegration tests applied in the empirical exchange rate literature usually pay little attention to the fact that nominal money supply potentially follows an $I(2)$ process, see Holtemöller (2004). In this paper, this is not an issue because we will deal with stationary monetary disequilibria derived from demand functions for real money (see Section 3).
} 
on income elasticities of money demands home and abroad. Moreover, e.g. Rapach and Wohar $(2002,2004)$, and Groen (2002) do not explicitly account for interest rate effects so that the fundamental exchange rate equation melts down to:

$$
s_{t}=\beta_{0}+\beta_{1}\left(m_{t}-m_{t}^{*}\right)+\beta_{3}\left(y_{t}-y_{t}^{*}\right)
$$

Finally, Mark and Sul (2001) assume unit income elasticities of money demand for both countries:

$$
s_{t}=\beta_{0}+\left(m_{t}-m_{t}^{*}\right)-\left(y_{t}-y_{t}^{*}\right)
$$

Simplifying assumptions on money demand have become increasingly popular in the empirical exchange rate literature. Yet, the empirical support for these assumptions is often poorly founded. The following section illustrates that many of these assumptions clearly contradict the evidence found for income and interest rate elasticities of the U.S. and European money demand.

\subsection{Monetary Disequilibria and the Exchange Rate}

The distinguishing feature of the monetary model compared to solely considering PPP for exchange rate determination is that it additionally considers the effect of monetary disequilibria in the home and foreign country on the exchange rate. Therefore, La Cour and MacDonald (2000) advocated analyzing the 'money-market building blocks' of the monetary model separately instead of restricting attention to the single long-run relation emphasized by the reduced form equation (4). In this case, the single errorcorrection term $u=e c^{p p p}+e c^{m^{*}}-e c^{m}-\lambda e c^{i r d}$ summarizes the deviations from all economic long-run relationships of the monetary model. Accordingly, the resulting error-correction equation of the exchange rate includes only the disequilibrium term $u$ :

$$
\Delta s_{t}=\gamma_{r} u_{t-1}+\ldots+\eta_{t}=\gamma_{r}\left(e c^{p p p}+e c^{m^{*}}-e c^{m}-\lambda e c^{i r d}\right)_{t-1}+\ldots+\eta_{t}
$$

While the speed of the adjustment to the interest rate differential $\left(\gamma_{r} \lambda\right)$ is not identified in (8), it is assumed to be the same $\left(\gamma_{r}\right)$ for PPP and both monetary disequilibria, see Moersch and Nautz (2001). It is worth emphasizing that these restrictions on the adjustment dynamics of the exchange rate are not implied by the monetary model. It seems more natural to allow the exchange rate to adjust to deviations from the money demand relations (home and abroad) to the interest rate differential and to deviations from PPP in an unrestricted way. ${ }^{3}$ Therefore, we suggest the following structural errorcorrection equation for the exchange rate which separately accounts for the deviations

\footnotetext{
${ }^{3}$ Modeling deviations of the exchange rate from PPP in addition to deviations from economic fundamentals was also proposed by Mark and Sul (2001, p.41).
} 
of all relevant economic long-run relations including $e c^{m}, e c^{m^{*}}, e c^{p p p}$ and $e c^{i r d}$ :

$$
\Delta s_{t}=\gamma_{m} e c_{t-1}^{m}+\gamma_{m^{*}} e c_{t-1}^{m^{*}}+\gamma_{p p p} e c_{t-1}^{p p p}+\gamma_{i r d} e c_{t-1}^{i r d}+\sum_{j=1}^{k} \theta_{j} \Delta s_{t-j}+\epsilon_{t}
$$

Theory predicts particular signs for the different $\gamma$-coefficients: An excess money supply in Europe $\left(e c_{t-1}^{m}>0\right)$ is expected to result in a depreciation of the Euro $\left(\gamma_{m}>0\right)$, while an excess money supply in the U.S. $\left(e c_{t-1}^{m^{*}}>0\right)$ should be followed by an appreciation of the Euro against the Dollar $\left(\gamma_{m^{*}}<0\right)$. Furthermore, a positive deviation from $\operatorname{PPP}\left(e c_{t-1}^{p p p}>0\right)$ indicates an undervaluation of the Euro, which should lead to an appreciation $\left(\gamma_{p p p}<0\right)$. Moreover, a positive interest rate differential $\left(e c^{i r d}>0\right)$ might be followed by an appreciation of the Euro $\left(\gamma_{i r d}<0\right)$.

The analysis of exchange rate dynamics by means of the structural error-correction equation (9) requires the identification of the monetary disequilibria $e c^{m}$ and $e c^{m^{*}}$. Since inappropriate modeling of money demand would lead to misspecified monetary disequilibria, this paper proposes borrowing these estimates from the empirical money demand literature. The empirical analysis of the monetary exchange rate model should benefit from carefully specified money demand function in various ways. While standard reduced form exchange rate equations often imply implausible income and interest rate elasticities of money demand, the use of well-specified money demands provided by the literature avoids this problem. Similarly, there is no need to impose problematic parameter restrictions on income or interest rate elasticities. Finally, the structural exchange rate equation (9) does not impose arbitrary equality restrictions on the exchange rate dynamics.

The following Section 3 reviews the monetary disequilibria presented in the recent literature on U.S. and European money demand functions. The impact of the different estimates for the monetary disequilibria on the Euro/Dollar exchange rate is examined in Section 4.

\section{Money Demand and Monetary Disequilibria}

\subsection{Money Demand in the U.S.}

Compared to the large number of recent contributions on European money demand, there are only a few studies on money demand in the United States. This might reflect the minor role of monetary aggregates within the monetary strategy of the Federal Reserve Bank. A very comprehensive study on U.S. money demand is provided by Carlson et al. (2000). They find evidence for a stable money demand relationship with 
regard to the broad monetary aggregate M2 when controlling for episodes of financial innovation in the nineties. Focusing on the aggregates M2M and MZM, which exclude small time deposits, they control for effects of households' portfolio reallocation which might be responsible for the instability of the M2 money demand relation detected by Miyao (1996).

Figure 1 depicts monetary disequilibria implied by different money demand functions for M2M and MZM as estimated by Carlson et al. (2000). One observes large equilibrium deviations during the 'monetaristic experiment' (1979-1982) at the beginning of the eighties, but these deviations become smaller around 1985. In the early nineties there was an excess money supply, which disappeared by the end of 1995 . Table 1 shows that the estimated long-run elasticities of money demand differ when e.g. different measures for the opportunity costs of money holdings are used. Yet, the implied monetary disequilibria identified by Carlson et al. (2000) are remarkably similar.

Figure 1: U.S. Monetary Disequilibria 1976:1-1998:4

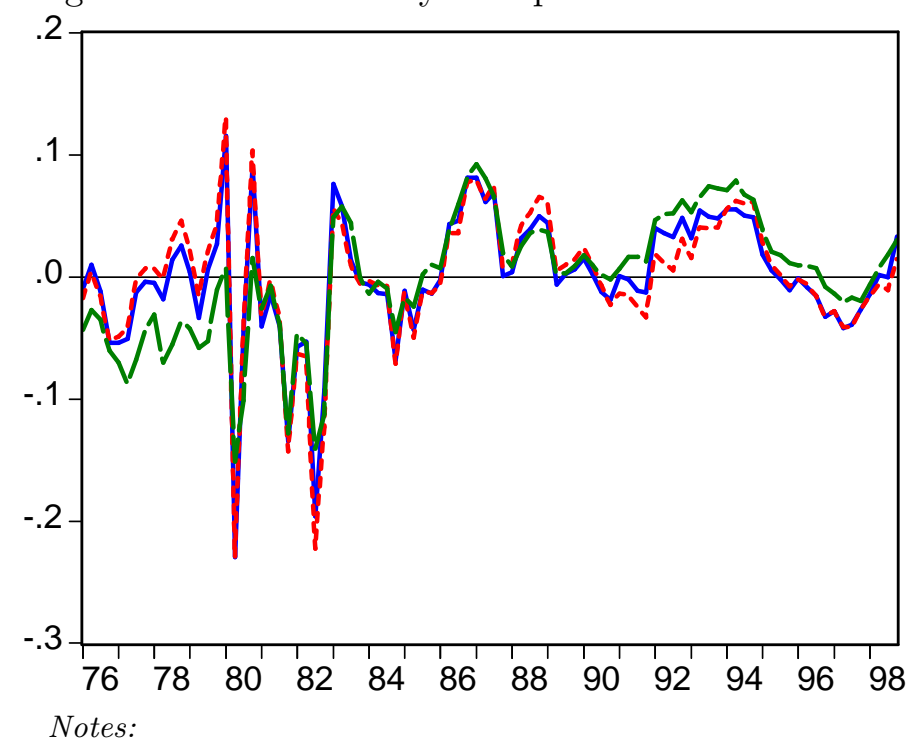

Monetary disequilibria are calculated from the money demand relations for M2M and MZM; see Carlson et al. (2000), Tables 3/4/10 (upper panels, specification with 6 lags) 


\subsection{Money Demand in Europe}

Due to the important role of monetary aggregates for the monetary policy of the European Central Bank (ECB), the European money demand has been very well researched. ${ }^{4}$ Table 1 surveys the long-run money demand relations estimated by various authors. These studies differ with respect to (1) the applied econometric methods, (2) the way they construct synthetic European data, and (3) the choice of variables:

(1) With regard to the econometric method one can distinguish between singleequation approaches (e.g. Funke 2001; Golinelli and Pastorello 2002) and approaches based on cointegrated vector-autoregressions (e.g. Kontolemis 2002; Müller 2003; Holtemöller 2004).

(2) There are different methods applied for constructing 'synthetic' Euro data: Some studies use area-wide data uniformly constructed by the index aggregation method, compare Fagan and Henry (1998, pp.503). Alternatively, the irrevocable fixed conversion rates are applied to express nominal variables in Euro (e.g. Brand and Cassola 2000; Müller 2003). Only a few authors present results for different aggregation methods (e.g. Brand et al. 2002; Bruggeman et al. 2003).

(3) There are differences concerning the choice of variables, especially with regard to the measure for opportunity costs of money holdings and the inclusion of the inflation rate.

Despite these differences in the empirical set up, all studies support the stability of European money demand. In particular, the estimated income and interest rate elasticities differ notably in some cases. However, the consequences and importance of these differences for monetary policy and the exchange rate are not obvious. The crucial point is whether differences in the estimated money demand functions also lead to pronounced differences in the corresponding monetary disequilibria. Following Carlson et al. (2000), we therefore computed monetary disequilibria for Europe derived from the reported money demand relationships as follows:

$$
e c_{t}^{m}=m_{t}-p_{t}-f_{t}
$$

where $f_{t}$ is the r.h.s. of the money demand relations reported in Table 1 . The resulting monetary disequilibria are displayed in Figure $2 .^{5}$

\footnotetext{
${ }^{4}$ The growing interest in the properties of a union-wide money demand resulted from the two-pillar strategy of the ECB where the the first pillar required a stable (European) money demand relation. Though the ECB has recently reduced the importance of monetary aggregates within its monetary strategy, a stable money demand relation remains important for money growth to be a reliable indicator for inflationary pressure.

${ }^{5}$ All disequilibria are mean-adjusted, whereby the mean is calculated over the respective estimation sample, see Table 1.
} 
Table 1: Recent Studies on Money Demand in Europe and the U.S.

\begin{tabular}{l|c|l}
\hline \multicolumn{1}{c|}{ Study } & Sample & \multicolumn{1}{c}{ Money Demand Relation } \\
\hline EMU: & & \\
Brand / Cassola (2000) & $1980: 1-1999: 3$ & $m_{t}-p_{t}=1.331 y_{t}-1.61 i_{t}^{l}$ \\
Coenen / Vega (2001) & $1980: 4-1998: 4$ & $m_{t}-p_{t}=1.125 y_{t}-0.865\left(i_{t}^{l}-i_{t}^{s}\right)-1.512 \pi_{t}$ \\
Funke (2001) & $1980: 3-1998: 4$ & $m_{t}-p_{t}=1.21 y_{t}-0.3 i_{t}^{s}+0.06 D 86$ \\
Brand et al. (2002) & $1980: 1-2001: 2$ & $m_{t}-p_{t}=1.34 y_{t}-0.45 i_{t}^{l}$ \\
Golinelli / Pastorello (2002) & $1980: 3-1997: 4$ & $m_{t}-p_{t}=1.373 y_{t}-0.681 i_{t}^{l}$ \\
Kontolemis (2002) & $1980: 1-2001: 3$ & $m_{t}-p_{t}=y_{t}-1.45 i_{t}^{s}$ \\
Holtemöller (2004) & $1984: 1-2001: 4$ & $m_{t}-p_{t}=1.275 y_{t}-0.751 i_{t}^{l}$ \\
Müller (2003) & $1984: 1-2000: 4$ & $m_{t}-p_{t}=1.57 y_{t}-2.22 i_{t}^{l}+1.87 i_{t}^{s}$ \\
Bruggeman et al. (2003) & $1981: 3-2001: 4$ & $m_{t}-p_{t}=1.25 y_{t}-\left(i_{t}^{s}-i_{t}^{\text {own }}\right)$ \\
\hline USA: & & \\
Carlson et al. (2000) & $1976: 1-1998: 12$ & $m_{t}-p_{t}=0.898 I P_{t}-5.274 o p p c o s t_{t}$ \\
& & $m_{t}-p_{t}=I P_{t}-4.612 o p p c o s t_{t}$ \\
\hline
\end{tabular}

\section{Description of the Variables}

(For a detailed description of the data and the aggregation method applied see the respective paper)

$m:(\log )$ nominal money supply

$p$ : (log) price level

$y:(\log )$ Gross Domestic Product (GDP)

$i^{l}$ : long-term nominal interest rate

$i^{s}$ : short-term nominal interest rate

$i^{\text {own }}$ : own-rate of M3 (see Bruggeman et al. 2003, p.37)

$\pi$ : annualized quarterly inflation (derived from GDP deflator; see Coenen / Vega 2001, p.731)

D86: dummy variable (see Funke 2001, p.705; also: Coenen / Vega 2001, p.733)

IP: (log) industrial production

oppcost: opportunity costs of holding money (see Carlson et al. 2000, p.349)
} 
Figure 2: European Monetary Disequilibria 1984:1-2002:4
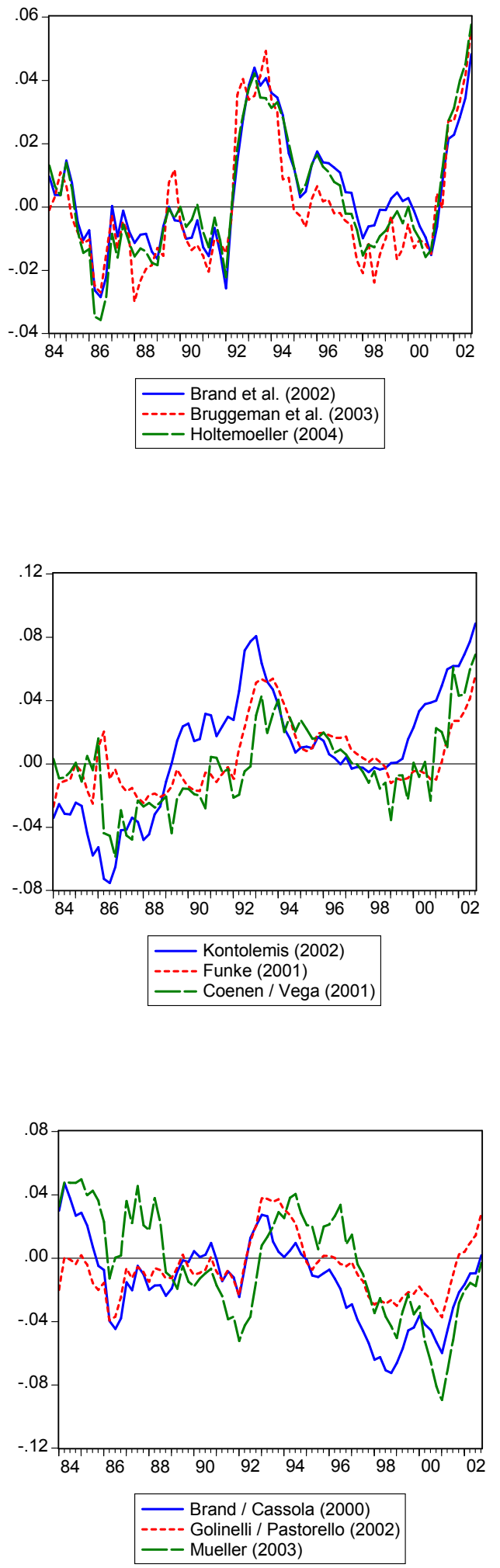
Most European money demand functions indicate an episode of excess money supply from 1992 up to (about) 1997 - a situation which also seems to be prevalent since mid-2001, although this is only supported by the money demand studies corresponding to the top and the middle figure.

In the following section, we investigate how the Euro/Dollar exchange rate responds to the monetary disequilibria identified by the empirical literature on U.S. and European money demand introduced above.

\section{Monetary Disequilibria and the Euro/Dollar Exchange Rate: Empirical Results}

\subsection{Data}

We used quarterly data within a common sample 1984:1-2002:4, see Table 1. Following Carlson et al. (2000) we took data from the Federal Reserve Bank of St. Louis (FRED II) for constructing the U.S. monetary disequilibria. These data were converted from monthly to quarterly frequency. Calculations for the European monetary disequilibria are based on the (synthetic) European data used in the respective study on European money demand. ${ }^{6}$

European time series were projected up to 2002:4 using growth rates of the respective variables from the Euro Area Statistic (EAS) of the ECB. In particular, we derived nominal and real money growth using the ECB series for (seasonally adjusted) M3 and the GDP deflator, whereby the latter was also used for computing (annualized) inflation. Furthermore, growth rates of real GDP were computed using the ECB series for nominal GDP and the GDP deflator.

For interest rates, the time series were expanded by the (quarterly averages of the) Euribor 3-month rate and the 10-year government bond yield. ${ }^{7}$

The synthetic Euro/Dollar exchange rate was constructed by backcasting the Euro/Dollar exchange rate series from the ECB since 1999 using a weighted sum of growth rates of 10 national bilateral exchange rates. In contrast to La Cour and MacDonald (2000), we

\footnotetext{
${ }^{6}$ We thank Claus Brand, Annick Bruggeman, Günter Coenen, Oliver Holtemöller and Christian Müller for providing us with the original data used for their analyses. Data for Golinelli and Pastorello (2002) are available at: http://www.spbo.unibo.it/pais/golinelli/macro.html. Funke (2001) essentially draws on the same dataset as Coenen and Vega (2001). Kontolemis (2002) expands the dataset of Brand and Cassola (2000) up to 2001:3. The U.S. data can be downloaded at http://research.stlouisfed.org/fred2.

7 The own rate of M3 as used in Bruggeman et al. (2003) was computed for the period 2002:1-2002:4 by a dynamic simulation of a regression $D\left(i_{t}^{\text {own }}\right)$ on $D\left(i_{t}^{s}\right)$ (within a sample 1994:2-2001:4) where $i_{t}^{s}$ is the Euribor 3-month rate obtained from the EAS. $D(\cdot)$ is the difference operator.
} 
do not consider the European Currency Unit (ECU), since the ECU included countries which have not joined the EMU (Denmark, United Kingdom). In contrast as well, Austria and Finland - which introduced the Euro in 1999 - were not included in the ECU. The fixed weights used for this index aggregation (see Fagan and Henry 1998) are GDP weights (1998) at PPP exchange rates.

\subsection{Structural Exchange Rate Equations}

After these preliminaries, we now turn to the estimation of the structural exchange rate equation (9):

$$
\Delta s_{t}=\gamma_{m} e c_{t-1}^{m}+\gamma_{m^{*}} e c_{t-1}^{m^{*}}+\gamma_{p p p} e c_{t-1}^{p p p}+\gamma_{i r d} e c_{t-1}^{i r d}+\sum_{j=1}^{k} \theta_{j} \Delta s_{t-j}+\epsilon_{t}
$$

where $e c^{p p p}$ and $e c^{i r d}$ denote the stationary deviations from PPP and the interest rate differential, and the monetary disequilibria $e c^{m}, e c^{m^{*}}$ are borrowed from the money demand studies introduced in Section $3 .^{8}$

Each combination of European and U.S. money demand functions leads to a different pair of monetary disequilibria $e c^{m}, e c^{m^{*}}$. However, the number of relevant combinations can be reduced because the various U.S. monetary disequilibria derived by Carlson et al. (2000) are very similar (see Figure 1). In fact, it can be shown that the following results will not depend substantially on the specific choice of the U.S. money demand function. In the following, we therefore present the results for each of the nine different European money demand functions reported in Table 1 and a representative U.S. monetary disequilibrium term $\left(e c^{m^{*}}=m^{*}-p^{*}-0.717 I P+5.245 o p p c o s t\right)$.

The left part of Table 2 shows the estimated adjustment parameters for the structural exchange rate equations. In most cases, the adjustment coefficients are significant and show the expected signs. The only exception is the negative but insignificant estimate for $\gamma_{m}$ obtained for the exchange rate equation based on the European money demand function provided by Müller (2003). The overall impression is that the estimated adjustment parameters are rather similar across the equations. With the exception of the exchange rate equation associated with Brand and Cassola (2000), the exchange rate tends to respond faster to monetary disequilibria than to deviations from $\operatorname{PPP}\left(\gamma_{p p p}\right)$.

\footnotetext{
8 The (log) U.S. GDP deflator and the $(\log )$ European GDP deflator enter the $e c^{p p p}$ term as foreign and domestic price levels whereas $e c^{i r d}$ includes the European and the U.S. 10-year government bond yield. According to standard unit root tests, both regressors can be viewed as stationary. For the sake of completeness, please note that all equations contain a constant and an impulse dummy D924 capturing the effects of exchange rate market turmoils in fall 1992.
} 
Table 2:

Adjustment Coefficients of Structural and Reduced Form Exchange Rate Equations

\begin{tabular}{|l|c|c|c|c||c|}
\cline { 2 - 6 } \multicolumn{1}{c|}{} & \multicolumn{4}{c||}{ structural equation $(9)$} & reduced form \\
\multicolumn{1}{c|}{} & \multicolumn{3}{c|}{ equation (8) } \\
\hline money demand study & $\hat{\gamma}_{m}$ & $\hat{\gamma}_{m^{*}}$ & $\hat{\gamma}_{p p p}$ & $\hat{\gamma}_{i r d}$ & $\hat{\gamma}_{r}$ \\
\hline Brand et al. & 0.511 & $-0.200^{*}$ & $-0.069^{* *}$ & $-1.569^{* * *}$ & $-0.072^{* * *}$ \\
& $(0.335)$ & $(0.119)$ & $(0.034)$ & $(0.532)$ & $(0.024)$ \\
Bruggeman et al. & $0.590^{*}$ & $-0.258^{* *}$ & $-0.074^{* *}$ & $-1.768^{* * *}$ & $-0.059^{*}$ \\
Holtemöller & $(0.329)$ & $(0.127)$ & $(0.034)$ & $(0.557)$ & $(0.034)$ \\
& $0.628^{* *}$ & $-0.244^{* *}$ & $-0.066^{* *}$ & $-1.682^{* * *}$ & $-0.073^{* * *}$ \\
\hline Kontolemis & $(0.307)$ & $(0.121)$ & $(0.033)$ & $(0.531)$ & $(0.027)$ \\
& $0.424^{* *}$ & $-0.298^{* *}$ & -0.046 & $-1.762^{* * *}$ & $-0.039^{* *}$ \\
Funke & $(0.160)$ & $(0.124)$ & $(0.034)$ & $(0.522)$ & $(0.018)$ \\
& 0.323 & $-0.209^{*}$ & $-0.059^{*}$ & $-1.542^{* * *}$ & $-0.068^{*}$ \\
Coenen / Vega & $(0.286)$ & $(0.124)$ & $(0.035)$ & $(0.539)$ & $(0.035)$ \\
& $0.550^{* *}$ & $-0.247^{* *}$ & $-0.068^{* *}$ & $-1.695^{* * *}$ & -0.001 \\
\hline Brand / Cassola & $0.216)$ & $(0.118)$ & $(0.034)$ & $(0.518)$ & $(0.001)$ \\
Golinelli / Pastorello & $0.470^{*}$ & -0.093 & $-0.124^{* * *}$ & $-2.047^{* * *}$ & $-0.072^{* *}$ \\
Müller & $0.263)$ & $(0.115)$ & $(0.041)$ & $(0.741)$ & $(0.033)$ \\
& $(0.332)$ & $-0.206^{*}$ & $-0.068^{* *}$ & $-1.789^{* * *}$ & $-0.058^{* *}$ \\
& -0.059 & -0.130 & $(0.034)$ & $(0.575)$ & $(0.023)$ \\
& $(0.160)$ & $(0.119)$ & $-0.070^{*}$ & $-1.243^{* *}$ & $-0.075^{* *}$ \\
\hline
\end{tabular}

Notes: Column 1 characterizes the money demand study associated with the European monetary disequilibrium $\left(e c^{m}\right)$ included in the exchange rate equations. The representative U.S. disequilibrium is $e c^{m^{*}}=m^{*}-p^{*}-0.717 I P+5.245$ oppcost.

Column 2-5 report the estimates for the adjustment coefficients for the different disequilibria. Column 6 shows the parameter estimates for the adjustment coefficient of the exchange rate equation (8).*/**/*** denotes significance at the $10 \%-/ 5 \% / 1 \%$-level (standard errors in parentheses).

In order to assess the potential benefits of the structural exchange rate equations, we estimated the corresponding standard reduced form exchange rate equation as specified in (8):

$$
\Delta s_{t}=\gamma_{r} u_{t-1}+\sum_{j=1}^{k} \theta_{j, r} \Delta s_{t-j}+\eta_{t}
$$

The reduced form equilibrium deviations $u_{t}$ are estimated with the Johansen procedure based on vector error-correction models for the reduced system $z=\left(s, m, m^{*}, y, y^{*}, i, i^{*}\right)$, imposing a cointegration rank of $r=1$. The employed data set depends on the specific money demand study and, thus, consists of exactly the same time series used for defining $e c^{m}$ and $e c^{m^{*}}$. As a result, we obtain pairs of structural and reduced form equations for the Euro/Dollar exchange rate which are directly comparable.

The right column of Table 2 presents the estimated adjustment coefficient of the reduced form exchange rate equations $\left(\hat{\gamma}_{r}\right)$. The results are promising. All adjustment coefficients show the expected negative sign and are (almost) always significant. It 
is therefore not obvious whether estimating a structural exchange rate equation that explicitly builds on the money demand literature was really worth the effort. In the following section we therefore investigate the equations' ability to track the exchange rate path both in-sample and out-of-sample.

\subsection{Out-of-Sample Evaluation: Predictive Regressions}

Let us first investigate the out-of-sample performance of the structural and the reduced form exchange rate equations. Along the lines of Mark (1995) or Rapach and Wohar (2004), we computed $k$-step-ahead forecasts for the Euro/Dollar exchange rate by means of predictive regressions

$$
\Delta s_{t+k}=c+\tilde{\gamma}_{m} e c_{t}^{m}+\tilde{\gamma}_{m^{*}} e c_{t}^{m^{*}}+\tilde{\gamma}_{p p p} e c_{t}^{p p p}+\tilde{\gamma}_{i r d} e c_{t}^{i r d}+\phi_{t}
$$

starting with the first 50 sample observations. Recursive estimation of (11) by successively expanding the sample by one observation provided series of 1-/4-/8-/12- and 16 -step-ahead forecasts. These forecasts were computed for each structural exchange rate equation presented in Table 2.

Predictive regressions for the corresponding reduced form equations were computed in an analogous way:

$$
\Delta s_{t+k}=c+\tilde{\gamma}_{r} u_{t}+\phi_{t}^{r}
$$

where $u_{t}$ are the reduced form residuals. Table 3 reports ratios of Root Mean Squared Errors (RMSEs) for the structural and the reduced form equation for the various forecast horizons. Ratios smaller than 1 indicate a better performance of the structural exchange rate equation.

Table 3: Out-of-Sample Forecast Comparison of Structural and Reduced Form Exchange Rate Equations

\begin{tabular}{l|c|c|c|c|c}
\hline money demand study & 1-step & 4-step & 8 -step & 12-step & 16-step \\
\hline Brand et al. & 0.981 & 0.794 & 0.791 & 0.903 & 0.700 \\
Bruggeman et al. & 1.025 & 0.794 & 0.801 & 0.884 & 0.565 \\
Holtemöller & 0.951 & 0.775 & 0.824 & 0.904 & 0.698 \\
Kontolemis & 1.009 & 0.836 & 1.013 & 0.995 & 0.748 \\
Funke & 1.010 & 0.774 & 0.850 & 0.879 & 0.670 \\
Coenen / Vega & 0.953 & 0.821 & 0.836 & 0.833 & 0.692 \\
Brand / Cassola & 1.049 & 0.942 & 0.735 & 0.729 & 0.919 \\
Golinelli / Pastorello & 1.034 & 0.952 & 0.771 & 0.807 & 0.751 \\
Müller & 1.100 & 1.204 & 1.118 & 1.132 & 0.948 \\
\hline
\end{tabular}

Notes: Column 1 characterizes the money demand study associated with the European monetary disequilibrium $\left(e c^{m}\right)$ included in the structural predictive equation (11). The table entries report the ratios of Root Mean Squared Errors where values smaller than 1 indicate a better performance of the structural predictive equation. 
According to Table 3, the RMSE-ratios for the one-step-ahead predictions are very close to 1 . However, from forecast horizon $h=4$ onwards we can observe a substantial forecast improvement by the structural equation compared to the reduced form alternative. At forecast horizon $h=16$, we sometimes obtain RMSE-reductions even above $30 \%$. The only exception is associated with Müller (2003), where the performance of the structural equation is relatively poor. Recall, however, that the estimated adjustment coefficients of that structural equation were partly implausibly signed, see Table 2 .

The predictive regressions show that the structural specification outperforms the standard reduced form exchange rate equations in the medium and long-run. Therefore, incorporating results from the money demand literature seems to increase the predictive ability of monetary exchange rate equations.

\subsection{In-Sample Evaluation: Dynamic Simulations}

The focus of the current paper is, however, not exclusively on the out-of-sample forecasting performance of the exchange rate equation but also on the investigation of "the extent to which monetary fundamentals matter at all for nominal exchange rate dynamics," see Mark and Sul (2001, p.31).

We therefore use conditional dynamic simulations over the estimation period as an additional tool to investigate an equation's ability to track the exchange rate path insample. Conditional dynamic simulations have been widely used in the exchange rate literature since Meese and Rogoff (1983). These simulations are (1) conditional because they are based on the realized values of the fundamentals and (2) dynamic since the lagged values of the exchange rate are determined endogenously. Table 4 reports the RMSE criterion to summarize the results of the dynamic simulations for each pair of exchange rate equations.

The dynamic simulations of the exchange rate equations provide strong evidence in favor of the structural specification. Irrespective of the money demand function being examined, the structural equation clearly outperforms its reduced form counterpart. 
Table 4: Root Mean Squared Errors of Dynamic Simulations

\begin{tabular}{l|c|c}
\hline money demand study & $\begin{array}{c}\text { structural } \\
\text { exchange rate equation }\end{array}$ & $\begin{array}{c}\text { reduced form } \\
\text { exchange rate equation }\end{array}$ \\
\hline Brand et al. & 0.1517 & 0.3111 \\
Bruggeman et al. & 0.1319 & 0.3708 \\
Holtemöller & 0.1148 & 0.3294 \\
Kontolemis & 0.0655 & 0.2073 \\
Funke & 0.1380 & 0.3622 \\
Coenen / Vega & 0.0847 & 0.3083 \\
Brand / Cassola & 0.1945 & 0.3111 \\
Golinelli / Pastorello & 0.1662 & 0.2455 \\
Müller & 0.1158 & 0.2108 \\
\hline
\end{tabular}

Notes: Column 1 characterizes the money demand study associated with the European monetary disequilibrium $\left(e c^{m}\right)$ included in the structural exchange rate equation (9). Column 2-3 show the RMSE-values for the simulations obtained from the structural equations and the reduced form equations.

\section{Concluding Remarks}

Stable money demand functions are necessary conditions for the validity of the monetary model of the exchange rate. Yet the empirical exchange rate literature typically ignores results provided by money demand literature. This paper examined whether the empirical evidence for the monetary exchange rate model can be improved if both strands of the literature are brought together. For this purpose, we investigated whether deviations from U.S. and European long-run money demands provided by the literature influence the Euro/Dollar exchange rate as theory predicts.

Building on the results of money demand literature circumvents several problems of the empirical exchange rate literature recently illustrated in a comprehensive countryby-country investigation by Rapach and Wohar (2004). For example, long-run elasticities home and abroad are not assumed to be identical. This is a popular assumption in the exchange rate literature which clearly contradicts recent estimates of U.S. and European money demand functions. Thus, incorporating results from the money demand literature ensures that the exchange rate model is based on sensible money demand specifications and plausible estimates of income and interest rate elasticities. In line with the theoretical predictions of the monetary model, our empirical results show that the Euro/Dollar exchange rate responds to monetary disequilibria in a plausible manner. 
Dynamic simulations and predictive regressions indicate that structural exchange rate equations can outperform standard reduced form specifications - which do not incorporate previous knowledge about money demand functions - in-sample and out-of-sample. In confirmation of what Smith and Wickens (1986) had suspected early on, this shows that the performance of empirical exchange rate models can be improved substantially by taking insights from the money demand literature into account.

\section{References}

Brand, C. and Cassola, N. (2000). A Money Demand System for Euro Area M3. Working Paper No.39, European Central Bank.

Brand, C., Roffia, B. and Gerdesmeier, D. (2002). Estimating the Trend of M3 Income Velocity Underlying the Reference Value of Monetary Growth. Occasional Paper No.3, European Central Bank, Frankfurt (Main).

Bruggeman, A., Donati, P. and Warne, A. (2003). Is the Demand for Euro Area M3 Stable? Working Paper No. 255, European Central Bank, Frankfurt (Main).

Carlson, J. B., Hoffman, D. L., Keen, B. D. and Rasche, R. H. (2000). Results of a Study of the Stability of Cointegrating Relations Comprised of Broad Monetary Aggregates. Journal of Monetary Economics, 46:345-383.

Cheung, Y.-W., Chinn, M. D. and Pascual, A. G. (2002). Empirical Exchange Rate Models of the Nineties: Are Any Fit to Survive? NBER Working Paper No. 9393.

Coenen, G. and Vega, J.-L. (2001). The Demand for M3 in the Euro Area. Journal of Applied Econometrics, 16:727-748.

Fagan, G. and Henry, J. (1998). Long Run Money Demand in the EU: Evidence for Area-Wide Aggregates. Empirical Economics, 23:483-506.

Funke, M. (2001). Money Demand in Euroland. Journal of International Money and Finance, 20:701-713.

Golinelli, R. and Pastorello, S. (2002). Modeling the Demand for M3 in the Euro Area. The European Journal of Finance, 8:371-401. 
Groen, J. J. J. (2000). The Monetary Exchange Rate Model as a Long-Run Phenomenon. Journal of International Economics, 52:299-319.

Groen, J. J. J. (2002). Cointegration and the Monetary Exchange Rate Model Revisited. Oxford Bulletin of Economics and Statistics, 64(4):361-380.

Holtemöller, O. (2004). A Monetary Vector Error Correction Model of the Euro Area and Implications for Monetary Policy. Empirical Economics, 29:553-574.

Kim, B. and Mo, S. (1995). Cointegration and the Long-Run Forecasts of Exchange Rates. Economics Letters, 48:353-359.

Kontolemis, Z. G. (2002). Money Demand in the Euro Area: Where Do We Stand (Today)? IMF Working Paper No. 02/185, International Monetary Fund, Washington.

La Cour, L. and MacDonald, R. (2000). Modeling the ECU Against the U.S. Dollar: A Structural Monetary Interpretation. Journal of Business and Economic Statistics, 18(4):436-449.

MacDonald, R. and Marsh, I. W. (1997). On Fundamentals and Exchange Rates: A Casselian Perspective. Review of Economics and Statistics, 79:655-664.

MacDonald, R. and Taylor, M. (1994). The Monetary Model of the Exchange Rate: Long-Run Relationships, Short Run Dynamics and How to Beat a Random Walk. Journal of International Money and Finance, 13:276-290.

Mark, N. C. (1995). Exchange Rates and Fundamentals: Evidence on Long-Horizon Predictability. The American Economic Review, 85(1):201-218.

Mark, N. C. and Sul, D. (2001). Nominal Exchange Rates and Monetary Fundamentals: Evidence from a Small Post-Bretton Woods Panel. Journal of International Economics, 53:29-52.

Meese, R. and Rogoff, K. (1983). Empirical Exchange Rate Models of the Seventies. Do They Fit Out of Sample? Journal of International Economics, 14:3-24.

Miyao, R. (1996). Does a Cointegrating M2 Demand Relation Really Exist in the United States? Journal of Money, Credit and Banking, 28(3.1):365-380.

Müller, C. (2003). Money Demand in Europe. An Empirical Approach. Physica-Verlag Heidelberg. 
Moersch, M. and Nautz, D. (2001). A Note on Testing the Monetary Model of the Exchange Rate. Applied Financial Economics, 11:261-268.

Moosa, I. (1994). The Monetary Model of the Exchange Rate Revisited. Applied Financial Economics, 26:279-287.

Oh, K.-Y. (1999). Are Exchange Rates Cointegrated with Monetary Model in Panel Data? International Journal of Finance and Economics, 4:147-154.

Rapach, D. E. and Wohar, M. E. (2002). Testing the Monetary Model of Exchange Rate Determination: New Evidence from a Century of Data. Journal of International Economics, 58:359-385.

Rapach, D. E. and Wohar, M. E. (2004). Testing the Monetary Model of Exchange Rate Determination: A Closer Look at Panels. Journal of International Money and Finance, 23:867-895.

Smith, P. N. and Wickens, M. R. (1986). An Empirical Investigation Into the Causes of Failure of the Monetary Model of the Exchange Rate. Journal of Applied Econometrics, 1(2):143-162. 


\section{The following Discussion Papers have been published since 2004:}

\section{Series 1: Economic Studies}

12004 Foreign Bank Entry into Emerging Economies:

An Empirical Assessment of the Determinants and Risks Predicated on German FDI Data Torsten Wezel

22004 Does Co-Financing by Multilateral Development

Banks Increase "Risky" Direct Investment in

Emerging Markets? -

Evidence for German Banking FDI Torsten Wezel

32004 Policy Instrument Choice and Non-Coordinated Giovanni Lombardo Monetary Policy in Interdependent Economies Alan Sutherland

$42004 \quad$ Inflation Targeting Rules and Welfare in an Asymmetric Currency Area Giovanni Lombardo

$52004 \quad$ FDI versus cross-border financial services: Claudia M. Buch The globalisation of German banks Alexander Lipponer

$62004 \quad$ Clustering or competition? The foreign Claudia M. Buch investment behaviour of German banks Alexander Lipponer

72004 PPP: a Disaggregated View Christoph Fischer

82004 A rental-equivalence index for owner-occupied Claudia Kurz housing in West Germany 1985 to 1998 Johannes Hoffmann

92004 The Inventory Cycle of the German Economy Thomas A. Knetsch

$102004 \quad$ Evaluating the German Inventory Cycle Using Data from the Ifo Business Survey Thomas A. Knetsch

$112004 \quad$ Real-time data and business cycle analysis in Germany

Jörg Döpke 
122004 Business Cycle Transmission from the US

to Germany - a Structural Factor Approach Sandra Eickmeier

132004 Consumption Smoothing Across States and Time: George M.

International Insurance vs. Foreign Loans von Furstenberg

142004 Real-Time Estimation of the Output Gap

in Japan and its Usefulness for

Inflation Forecasting and Policymaking Koichiro Kamada

$152004 \quad$ Welfare Implications of the Design of a

Currency Union in Case of Member Countries

of Different Sizes and Output Persistence Rainer Frey

162004 On the decision to go public: Ekkehart Boehmer

Evidence from privately-held firms Alexander Ljungqvist

$172004 \quad$ Who do you trust while bubbles grow and blow?

A comparative analysis of the explanatory power

of accounting and patent information for the

Fred Ramb

market values of German firms

Markus Reitzig

182004 The Economic Impact of Venture Capital

Astrid Romain, Bruno

van Pottelsberghe

192004 The Determinants of Venture Capital:

Astrid Romain, Bruno

Additional Evidence

van Pottelsberghe

$202004 \quad$ Financial constraints for investors and the

speed of adaption: Are innovators special? Ulf von Kalckreuth

$212004 \quad$ How effective are automatic stabilisers?

Theory and results for Germany and other Michael Scharnagl

OECD countries

Karl-Heinz Tödter 
$232004 \quad$ Financial Liberalization and Business

Cycles: The Experience of Countries in

Lúcio Vinhas the Baltics and Central Eastern Europe

de Souza

$24 \quad 2004 \quad$ Towards a Joint Characterization of Monetary Policy and the Dynamics of the Term Structure of Interest Rates

Ralf Fendel

252004 How the Bundesbank really conducted monetary policy: An analysis based on real-time data

Christina Gerberding Andreas Worms

Franz Seitz

262004 Real-time Data for Norway:

T. Bernhardsen, Ø. Eitrheim, Challenges for Monetary Policy

A.S. Jore, Ø. Røisland

$272004 \quad$ Do Consumer Confidence Indexes Help

Forecast Consumer Spending in Real Time?

Dean Croushore

$28 \quad 2004 \quad$ The use of real time information in

Maritta Paloviita

Phillips curve relationships for the euro area

David Mayes

292004 The reliability of Canadian output

Jean-Philippe Cayen

gap estimates

Simon van Norden

$302004 \quad$ Forecast quality and simple instrument rules -

Heinz Glück

a real-time data approach

Stefan P. Schleicher

$312004 \quad$ Measurement errors in GDP and

Peter Kugler

forward-looking monetary policy:

Thomas J. Jordan

The Swiss case

Carlos Lenz

Marcel R. Savioz 
$332004 \quad$ Interest rate reaction functions for the euro area Evidence from panel data analysis

Karsten Ruth

342004 The Contribution of Rapid Financial

Development to Asymmetric Growth of

Manufacturing Industries:

George M.

Common Claims vs. Evidence for Poland von Furstenberg

$352004 \quad$ Fiscal rules and monetary policy in a dynamic stochastic general equilibrium model

Jana Kremer

362004 Inflation and core money growth in the

Manfred J.M. Neumann euro area

Claus Greiber

372004 Taylor rules for the euro area: the issue

Dieter Gerdesmeier of real-time data

Barbara Roffia

$38 \quad 2004 \quad$ What do deficits tell us about debt?

Empirical evidence on creative accounting Jürgen von Hagen with fiscal rules in the EU Guntram B. Wolff

$392004 \quad$ Optimal lender of last resort policy

Falko Fecht

in different financial systems Marcel Tyrell

$40 \quad 2004 \quad$ Expected budget deficits and interest rate swap

Kirsten Heppke-Falk spreads - Evidence for France, Germany and Italy Felix Hüfner

$412004 \quad$ Testing for business cycle asymmetries based on autoregressions with a Markov-switching intercept Malte Knüppel

12005 Financial constraints and capacity adjustment in the United Kingdom - Evidence from a Ulf von Kalckreuth large panel of survey data Emma Murphy 
22005 Common stationary and non-stationary

factors in the euro area analyzed in a

large-scale factor model Sandra Eickmeier

32005 Financial intermediaries, markets,

F. Fecht, K. Huang, and growth

A. Martin

42005 The New Keynesian Phillips Curve

in Europe: does it fit or does it fail?

Peter Tillmann

52005 Taxes and the financial structure

Fred Ramb

of German inward FDI

A. J. Weichenrieder

62005 International diversification at home

Fang Cai

and abroad

Francis E. Warnock

72005 Multinational enterprises, international trade, and productivity growth: Firm-level evidence Wolfgang Keller from the United States

Steven R. Yeaple

82005 Location choice and employment

S. O. Becker,

decisions: a comparison of German

K. Ekholm, R. Jäckle,

and Swedish multinationals

M.-A. Muendler

92005 Business cycles and FDI:

Claudia M. Buch

evidence from German sectoral data

Alexander Lipponer

102005 Multinational firms, exclusivity,

Ping Lin

and the degree of backward linkages

Kamal Saggi

$112005 \quad$ Firm-level evidence on international

Robin Brooks

stock market comovement

Marco Del Negro

122005 The determinants of intra-firm trade: in search

Peter Egger

for export-import magnification effects

Michael Pfaffermayr 
132005 Foreign direct investment, spillovers and absorptive capacity: evidence from quantile regressions

Sourafel Girma

Holger Görg

142005 Learning on the quick and cheap: gains

James R. Markusen

from trade through imported expertise

Thomas F. Rutherford

152005 Discriminatory auctions with seller discretion:

evidence from German treasury auctions

Jörg Rocholl

162005 Consumption, wealth and business cycles:

B. Hamburg,

why is Germany different?

M. Hoffmann, J. Keller

172005 Tax incentives and the location of FDI:

Thiess Buettner

evidence from a panel of German multinationals Martin Ruf

182005 Monetary Disequilibria and the

Dieter Nautz

Euro/Dollar Exchange Rate

Karsten Ruth 


\section{Series 2: Banking and Financial Studies}

$12004 \quad$ Forecasting Credit Portfolio Risk

A. Hamerle,

T. Liebig, H. Scheule

22004 Systematic Risk in Recovery Rates -

An Empirical Analysis of US Corporate

Credit Exposures

Klaus Düllmann

Monika Trapp

32004 Does capital regulation matter for bank

Frank Heid

behaviour? Evidence for German savings

Daniel Porath

banks

Stéphanie Stolz

$42004 \quad$ German bank lending during

F. Heid, T. Nestmann,

emerging market crises:

B. Weder di Mauro,

A bank level analysis

$\mathrm{N}$. von Westernhagen

$52004 \quad$ How will Basel II affect bank lending to

T. Liebig, D. Porath, emerging markets? An analysis based on

B. Weder di Mauro,

German bank level data

M. Wedow

$62004 \quad$ Estimating probabilities of default for

German savings banks and credit cooperatives Daniel Porath

12005 Measurement matters - Input price proxies

and bank efficiency in Germany

Michael Koetter

22005 The supervisor's portfolio: the market price risk of German banks from 2001 to 2003 Analysis and models for risk aggregation

Christoph Memmel

Carsten Wehn 


\section{Visiting researcher at the Deutsche Bundesbank}

The Deutsche Bundesbank in Frankfurt is looking for a visiting researcher. Visitors should prepare a research project during their stay at the Bundesbank. Candidates must hold a $\mathrm{Ph} \mathrm{D}$ and be engaged in the field of either macroeconomics and monetary economics, financial markets or international economics. Proposed research projects should be from these fields. The visiting term will be from 3 to 6 months. Salary is commensurate with experience.

Applicants are requested to send a $\mathrm{CV}$, copies of recent papers, letters of reference and a proposal for a research project to:

Deutsche Bundesbank

Personalabteilung

Wilhelm-Epstein-Str. 14

D - 60431 Frankfurt

GERMANY 
